\title{
Determination of cation exchange capacity and analysis of cation availability in hemic and sapric peat with different preparation and extraction methods
}

\author{
Mirna Anriani Siregar, Azwar Ma'as*, and Makruf Nurudin \\ Department of Soil Science, Faculty of Agriculture, Universitas Gadjah Mada \\ Jln. Flora no. 1, Bulaksumur, Sleman, Yogyakarta 55281, Indonesia \\ *Corresponding author: azwar.maas@gmail.com
}

\section{Article Info}

Received : $11^{\text {th }}$ December 2019 Revised : $13^{\text {th }}$ November 2020 Accepted: $23^{\text {rd }}$ December 2020

Keywords:

Hydrophobicity, leaching, peat soil, shaking

\begin{abstract}
The use of mineral soil analysis procedures in peat soils is considered unsuitable. Peat soil is vulnerable to disturbance, which leads to the damage of peat inert structure, such as the sifting and drying process. The objective of this study was to obtain the proper methods of preparation and extraction to be used in peat soils that can reflect the conditions on field. The experiment was carried out in the laboratory of Soil Science Department UGM by using the peat soil samples taken from Padang Island, Riau, arranged in a factorial randomized block design with three factors (peat soil preparation, the extraction method, and the level of peat maturity). The variables observed included the available cation and Cation Exchange Capacity (CEC) of the peat soil. The results showed that there was no significant effect of the treatment interactions on each variable observed. The preparation method for original soil at each level of peat maturity reflected more of the physical condition on the field more than other methods. Meanwhile, sapric peat showed significant effect on cations and CEC. After being converted to bulk density (BD) values at each level of peat maturity, the result of the leaching extraction method showed that the value of available cation and CEC that reflected more of the value on the field. The peat soil analysis method should be carried out without air drying and shaking extraction treatment for further research.
\end{abstract}

\section{INTRODUCTION}

Peatlands in their natural state are always wet throughout the year and can be flooded in the rainy season. Peatlands are a typical type of land characterized by the accumulation of organic matter that partially decays and forms peat layers (Charman, 2009).

Excessive draining of peatland will result in non-reversal events and changes in the chemical nature of the peat. McCormick et al. (2011) stated that peatlands going through the drying process it will experience changes in the hydrological conditions of the land as well as the chemical nature of the peat soils, which have the potential to disrupt ecosystem stability. Excessive removal of water in peat soil will cause the peat layer to become dry and difficult to be re-wetted (non-reverse hydrophobicity) (Winarna, 2015). Hydrophobicity is either a nature or ability of soil (peat soil) to hold water in low power or a soil surface state that can no longer bind water (Szajdak dan Szatylowicz, 2010). Hydrophobicity is caused by a decrease in total acidity, carboxyl groups, and hydroxyphenolate content (Utami et al., 2009b; Wu et al., 2020). Masganti (2012) added that in the laboratory, hydrophobic peat soil would produce a biased value in the analysis of chemical properties. The impact after the drying process will partially destroy the structure of the peat so that a greater load arises from the natural conditions in addition to breaking and damaging of the inert structure of the peat (Indrawati et al., 2018).

How to cite: Siregar, M.A., Ma'as, A., and Nurudin, M. (2019). Determination of cation exchange capacity and analysis of cation availability in hemic and sapric peat with different preparation and extraction methods. Ilmu Pertanian (Agricultural Science), 6(1), pp. 47-53. 
Peat soil extraction is generally equated with mineral soil extraction by using $\mathrm{NH}_{4} \mathrm{OAc} \mathrm{pH}$ 7. Peat soils dominated by transformed loads are highly dependent on the soil $\mathrm{pH}$ so that the use of a $\mathrm{pH} 7$ buffer solution will cause overestimated actual peat cation values (Dewis and Freitas, 1970). $\mathrm{NH}_{4} \mathrm{Cl}$ extraction is a neutral salt with no buffering ability so that it is adjustable to the extracted material.

The condition of the hydrophilic peat material is required to be maintained within the peat soil analysis to reflect conditions on field. Ma'as (2010) revealed that the results of mineral soil analysis are generally directly interpreted based on the absolute dry weight units only because the $B D$ factor is \pm 1 (BD mineral soil: $0.9 \mathrm{~g} . \mathrm{cm}^{-3}$ to $1.3 \mathrm{~g} . \mathrm{cm}^{-3}$ ). The BD in peat soils is lower than in mineral soils within the range of $0.05-0.20 \mathrm{~g} . \mathrm{cm}^{-3}$ so that the results of peat analysis should be consequently interpreted in $\mathrm{BD}$ units in order to reflect the conditions on field (Ma'as, 2010). Researches on land use and fertility of peat soil have been commonly done. However, there have not been many researches on the methods of preparation and extraction of peat soils to reflect the conditions on field. The bias value resulted from the commonly used analysis method has been the basis for developing theories to formulate more appropriate new methods. This research aimed to examine, interprete and compare the proper methods on peat soils that are able to reflect the conditions on field, which are expressed by the peat $B D$ values.

\section{MATERIALS AND METHODS}

Peat soil sampling was carried out on Padang Island, Riau $\left(1^{\circ} \mathrm{O}^{\prime} \mathrm{N} 102^{\circ} 21^{\prime} \mathrm{E}\right)$ and in that area, two levels of peat maturity found were hemic and sapric peat. The experiment was arranged in a threefactorial randomized design. The first factor was the peat preparation, consisting of original preparation, air-dried preparation and impacted air-dried preparation. The second factor was the level of peat maturity, consisting of hemic and sapric peat. Meanwhile, the third factor was the peat extraction method, consisting of shearing and leaching method. Each treatment combination was replicated three times.

\section{Peat soil preparation}

The preparation of original soil constituted of peat soils that were still wet based on the conditions on field (hydrophilic). Air-dried preparation was carried out by using the aerial-dried soil samples in \pm 5 days. Preparation of impacted air-dried soil used the soil sample that had been air dried before impacted and sieved ( $2 \mathrm{~mm}$ sieve).

\section{Shaking extraction}

The shaking extraction was carried out by using the tried extraction methods of shaking and leaching. The shaking method was done by using a shaker tool in the form of a centrifuge. Peat soil in the original, air-dried, and impacted air-dried conditions were weighed by $2.5 \mathrm{~g}$ before put into the tube. Peat soil samples were then dissolved with $20 \mathrm{~mL}$ of $\mathrm{NH}_{4} \mathrm{Cl}$. The mixture was centrifuged at $8000 \mathrm{rpm}$ speed for 10 minutes. The mixture was allowed to stand for 1 hour before filtered by using filter paper. The filtrate obtained was then used for the analysis of available cations ( $\mathrm{Ca}, \mathrm{Mg}$, and $\mathrm{K}$ ). The soil in filter paper was isolated by using $100 \mathrm{~mL}$ of $96 \%$ ethanol that was given in stages, then the remaining ethanol was discarded. The dried soil in the filter paper was isolated with $50 \mathrm{~mL} \mathrm{KCl} 10 \%$. Filtrate obtained was useful to determine the cation exchange capacity (CEC) (Balai Penelitian Tanah, 2009).

\section{Leach extraction}

The leaching extraction method was carried out by leaching $15 \mathrm{~g}$ of peat soil samples (original, airdried dried and impacted air-dried) using $50 \mathrm{~mL}$ of ammonium chloride $\left(\mathrm{NH}_{4} \mathrm{Cl}\right)$ in the lysymmetry tube. The end of the tube was covered with cotton functioning as the filtrate filter. The mixture was incubated for 3 days, and the filtrate was collected for determining the available cations ( $\mathrm{Ca}, \mathrm{Mg}$, and $\mathrm{K})$. Soil samples that were still in the dried lyrical tube were then isolated with $100 \mathrm{~mL}$ of $96 \%$ ethanol, which was given gradually, and the remaining ethanol was removed. As much as $50 \mathrm{~mL}$ of $10 \% \mathrm{KCl}$ was put into the lysymmetric tube, and the results of the filtrate were used to determine the CEC (Balai Penelitian Tanah, 2009).

\section{Interpretation based on conditions on the field}

The results obtained of the peat soils analysis were converted into peat BD using the weight factor of the peat volume itself.

Anova was performed to determine whether there was a significant difference between the three factors (variants) treatment, and the Duncan multiple 
range test at the $\alpha=5 \%$ was used to determine the best treatment.

\section{RESULTS AND DISCUSSION}

The results of bulk density (BD) analysis indicate the available cations and CEC of the peat, which are presented in Table $1-5$. The results of bulk density analysis under hydrophilic conditions show that higher level of peat decomposition have tendency to increase BD values of peat soil. Peat soil bulk density at hemic maturity level was $0.17 \mathrm{~g} . \mathrm{cm}^{-3}$ while at sapric maturity was $0.23 \mathrm{~g} . \mathrm{cm}^{-3}$. The bulk density of peat soil in Padang Island (Table 1) had the same trend with the result obtained by Winarna et al. (2016). Boelter (1969) and Lampela et al.
(2014) reported that during the decomposition process, organic peat particles decreased in size, producing smaller pores and higher volume weights.

The objective of various experiment methods of soil preparation and extraction was to obtain a method of analyzing peat soil that better reflects the conditions on field. Preparation of peat soils through drying and impacting leads to changes in the peat nature to reject water and damage the structure of the peat original character (Szajdak et al., 2020). Hydrophobic peat causes changes in the physical character of the peat soil from its original condition, which is hydrophilic. Perdana et al. (2017) reported that hydrophobic peat would not able to fully return to the initial mass (hydrophilic), which is due to the damaged structure of peat during the

Table 1. The bulk density (BD) value of peat soil taken from Padang and Tebing Tinggi Islands

\begin{tabular}{lc}
\hline Peat maturity level and preparation & $\mathrm{BD}\left(\mathrm{g} \cdot \mathrm{cm}^{-3}\right)$ \\
\hline Original hemic & 0.17 \\
Original sapric & 0.23 \\
\hline
\end{tabular}

Table 2. The peat maturity level, preparation method and various extraction to Ca-Available $\left(\mathrm{cmol}(+) \cdot \mathrm{kg}^{-1}\right)$

\begin{tabular}{lcc}
\hline Treatments & $\begin{array}{c}\text { Not converted to bulk } \\
\text { density multiplication }\end{array}$ & $\begin{array}{c}\text { Converted to bulk } \\
\text { density multiplication }\end{array}$ \\
\hline Maturity & $0.42 \mathrm{~b}$ & $0.07 \mathrm{~b}$ \\
Hemic & $0.61 \mathrm{a}$ & $0.14 \mathrm{a}$ \\
Sapric & $0.69 \mathrm{a}$ & $0.14 \mathrm{a}$ \\
\hline Extraction & $0.33 \mathrm{~b}$ & $0.07 \mathrm{~b}$ \\
Shaking & $0.11 \mathrm{a}$ \\
Leaching & $0.56 \mathrm{a}$ & $0.11 \mathrm{a}$ \\
\hline Preparation & $0.52 \mathrm{a}$ & $(-)$ \\
Original soil & $0.45 \mathrm{a}$ & $(-)$ \\
Air-dried & Impacted air-dried &
\end{tabular}


Table 3. Peat maturity level, preparation and extraction methods on various values of $\mathrm{Mg}$-available $\left(\mathrm{cmol}(+) \cdot \mathrm{kg}^{-1}\right)$

\begin{tabular}{lcc}
\hline Treatments & $\begin{array}{c}\text { Not converted to bulk } \\
\text { density multiplication }\end{array}$ & $\begin{array}{c}\text { Converted to bulk } \\
\text { density multiplication }\end{array}$ \\
\hline Maturity & $0.42 \mathrm{~b}$ & $0.07 \mathrm{~b}$ \\
Hemic & $0.61 \mathrm{a}$ & $0.14 \mathrm{a}$ \\
Sapric & & \\
\hline Extraction & $0.69 \mathrm{a}$ & $0.14 \mathrm{a}$ \\
Shaking & $0.33 \mathrm{~b}$ & $0.07 \mathrm{~b}$ \\
Leaching & & \\
\hline Preparation & $0.56 \mathrm{a}$ & $0.11 \mathrm{a}$ \\
Original soil & $0.52 \mathrm{a}$ & $0.11 \mathrm{a}$ \\
Air-dried & $0.45 \mathrm{a}$ & $0.09 \mathrm{a}$ \\
Impacted air-dried & $(-)$ & $(-)$ \\
\hline Interaction &
\end{tabular}

Remarks: The values followed by the same letters in the same column are not significantly different based on DMRT $\alpha=5 \%$; sign (-) indicates no interaction between factors.

Table 4. Various levels of peat maturity, preparation and extraction methods on K-available ( $\left.\mathrm{cmol}(+) . \mathrm{kg}^{-1}\right)$

\begin{tabular}{lcc}
\hline Treatments & $\begin{array}{c}\text { Not converted to bulk } \\
\text { density multiplication }\end{array}$ & $\begin{array}{c}\text { Converted to bulk } \\
\text { density multiplication }\end{array}$ \\
\hline Maturity & $0.25 \mathrm{~b}$ & $0.04 \mathrm{~b}$ \\
Hemic & $0.43 \mathrm{a}$ & $0.11 \mathrm{a}$ \\
Sapric & & $0.10 \mathrm{a}$ \\
\hline Extraction & $0.42 \mathrm{a}$ & $0.06 \mathrm{a}$ \\
Shaking & $0.26 \mathrm{a}$ & $0.04 \mathrm{~b}$ \\
Leaching & & $0.10 \mathrm{a}$ \\
Preparation & $0.11 \mathrm{~b}$ & $0.09 \mathrm{a}$ \\
Original soil & $0.47 \mathrm{a}$ & $(-)$ \\
Air-dried & $0.44 \mathrm{a}$ & $(-)$ \\
Impacted air-dried & Interaction &
\end{tabular}

Remarks: The values followed by the same letters in the same column are not significantly different based on DMRT $\alpha=5 \%$; sign (-) indicates no interaction between factors. 
Table 5. Various peat maturity levels, preparation method and extraction to cation exchange capacity $\left(\mathrm{cmol}(+) \cdot \mathrm{kg}^{-1}\right)$ value.

\begin{tabular}{lcc}
\hline Treatments & $\begin{array}{c}\text { Not converted to bulk } \\
\text { density multiplication }\end{array}$ & $\begin{array}{c}\text { Converted to bulk } \\
\text { density multiplication }\end{array}$ \\
\hline Maturity & $70.19 \mathrm{~b}$ & $11.93 \mathrm{~b}$ \\
Hemic & $90.29 \mathrm{a}$ & $20.76 \mathrm{a}$ \\
Sapric & $93.40 \mathrm{a}$ & $19.11 \mathrm{a}$ \\
\hline Extraction & $67.08 \mathrm{~b}$ & $13.58 \mathrm{~b}$ \\
Shaking & & $12.17 \mathrm{c}$ \\
Leaching & $60.26 \mathrm{c}$ & $16.77 \mathrm{~b}$ \\
\hline Preparation & $81.71 \mathrm{~b}$ & 20.11 a \\
Original soil & 98.75 a & $(-)$ \\
Air-dried & $(-)$ & \\
Impacted air-dried & Interaction &
\end{tabular}

drying process, causing irreversible drying.

The analysis results showed that peat soil extraction by shaking method tended to give higher values of $\mathrm{Ca}$ (Table 2), Mg (Table 3) compared to the leaching extraction before and after converted to bulk density values, but the cation $\mathrm{K}$ value did not significantly affect the shaking extraction, but based on the tables presented, there had been an increase of $\mathrm{K}$ with shaking extraction from leach extraction before and after converted to bulk density (Table 4). The same tendency was obtained by Zabowski and Ugolini (1990), shaking extraction damaged the structure of the peat due to the rapid rotation and air-drying process in the peat sample. Indrawati (2018) emphasizes that peat going through both drying and rapid rotation process will damage the inert structure and generate higher value. Leaching extraction does not go through a shearing process, which can damage the structure of the peat, so that it is less disturbed, in accordance with the condition of the peat soil, which is prone to disturbance. Zabowski and Ugolini (1990) also emphasize that extraction by leaching has a constant value and represents more of the condition on the field.

Based on the results of the interactions analysis between the three treatment factors, it was proven that they did not have significant effect on the values of $\mathrm{Ca}, \mathrm{Mg}, \mathrm{K}$, and CEC (Table 2 -5). The results showed that air-dried and impacted air-dried tended to result in higher $\mathrm{K}$ (Table 4) and CEC values (Table 5) than the original soil preparation before and after converted to bulk density values. The same trend was also obtained by Utami et al. (2009a), Maftu'ah et al. (2019) and Rechcigl et al. (2008). The drying and impacting process resulted in the finer size of the peat grains and damaged the structure of the peat, thereby leading to higher values of CEC and cation especially in sapric peat. Rechcigl et al. (2008) and Wang et al. (2018) confirmed structural damage and chemical changing in the soil during the air-drying process.

Peat soil with sapric maturity level tended to have higher values of $\mathrm{CEC}, \mathrm{Ca}, \mathrm{Mg}$ and $\mathrm{K}$ than peat soil with hemic maturity level before and after converted to $B D$ values (Table $2-5$ ). The same tendency was obtained by Hikmatullah et al. (2014). The high values of CEC and cations in peat soil with sapric maturity level was because sapric peat is more mature so that the decomposition level of organic matter is more advanced than hemic peat (Sudadi and Parwati, 2004). The analysis results on each chemical parameter showed a decrease in CEC value and available cations after being converted to bulk density values. This reflected the peat soils condition on the field more accurately. Ma'as (2010) emphasizes that the results of the analysis of peat data must be converted to heavy peat volumes to better reflect the condition on the field. 


\section{CONCLUSIONS}

The results of CEC and available cations without air-drying treatment were closer to the condition on the field. Generally, after converted to bulk density values, all treatments showed very low compared to before converted, in which sapric peat provided greater value than hemic peat. Original preparation of peat without impacting, sieving and extracting by leaching more reflected the physical condition on field compared to the calculation of bulk density. Meanwhile, the preparation of air-dried, impacted air-dried and extracted peat by shaking reflected the peat condition on field less accurately. The peat soil analysis method should be carried out without air drying and shaking extraction treatment for further research.

\section{ACKNOWLEDGMENT}

The authors would like to thank Badan Restorasi Gambut (BRG) for the financial support in this research.

\section{REFERENCES}

Boelter, D. H. (1969). Physical properties of peats as related to degree of decomposition. Soil Science of America Proceedings, 33, pp. 606-609.

Balai Penelitian Tanah. (2009). Petunjuk teknis analisis kimia tanah, tanaman, air, dan pupuk. $2^{\text {nd }}$ ed. Bogor: Balai Penelitian Tanah, pp. 200

Charman, D.J. (2009). Peat and peatlands. In: Likens, G.E. ed. Encyclopedia of Inland Waters. Amsterdam: Elsevier, pp. 541-548.

Dewis, J. and Freitas, F. (1970). Physical and chemical methods of soil and water analysis. $10^{\text {th }} \mathrm{ed}$. Rome: Food and Agriculture Organization, pp. 275.

Hikmatullah, Nugroho, K., and Sarwani, M. (2014). Characterizing the cultivated lowland peat soils in two physiography positions in Kalimantan, Indonesia. International Research Journal of Agricultural Science and Soil Science, 3(7), pp. 246-255.

Indrawati, U.S.Y.V., Ma'as, A., Utami, S.N.H., and Hanudin, E. (2018). Characteristic of three biochar types with different pyrolysis time as ameliorant of peat soil. Indian Journal of Agricultural Research, 51(5), pp. 458-462.

Lampela, M., Jauhiainen, J., and Vasander, H. (2014).
Surface peat structure and chemistry in a tropical peat swamp forest. Plant and Soil, 382(1-2), pp. 329-347.

Ma'as, A. 2010. Interpretasi gambut untuk budidaya. [online]. Available at: http://balittra.litbang. pertanian.go.id/index.php/berita/info-aktual/ 108-interpretasi-gambut-untuk-budidayapertanian. [Accessed 17 December 2020].

Maftuah, Fahmi, A., and Hayati, A. (2019). Changes in degraded peat land characteristic using FTIR-spectrocopy. IOP Conference Series: Earth and Environment Science, 393, pp. 012091.

Masganti. (2012). Sample preparation for peat material analysis. Prosiding Workshop on Sustainable Management Lowland for Rice Production, pp. 179-184.

McCormick, P.V., Harvey, J.W., and Crawford, E.S. (2011). Influence of changing water sources and mineral chemistry on the everglades ecosystem. Environmental Science and Technology, 41(Sup1), pp. 28-63.

Perdana, L.R., Ratnasari, N.G., Ramadhan, M.L., Palamba, P., Nasruddin, and Nugroho, Y. S. (2018). Hydrophilic and hydrophobic characteristics of dry peat. IOP Conference Series: Earth and Environmental Science, 105, pp. 012083.

Rechcigl, J.E., Payne, G.G., and Sanchez, C.A. (2008). Comparison of various soil drying techniques on extractable nutrients. Communications in Soil Science and Plant Analysis, 23(17-20), pp. 2347-2363.

Sudadi and Parwati. (2013). Pengaruh sifat ketidakbalikon tanah gambyang dihadapkan pada tingkat lengas dan lama inkubasi tertentu terhadap beberapa sifat kimianya. Sains Tanah, 4(1), pp. 17-20.

Szajdak, L. and Szatylowicz, J. (2010). Impact of drainage on hydrophobicity of fen peat-moorsh soils. Mires and Peat, 6, pp. 158-174.

Szajdak, L., Jezierski, A., Wegner, K., Meysner, T., and Szczepanski, M. (2020). Influence of drainage on peat organic matter: Implications for development, stability, and transformation. Molecules, 25(11), pp. 1-27.

Utami, S. N. H., Ma'as, A., Radjagukguk, B., and Purwanto, B. H. (2009a). Restorasi gambut dengan tiga jenis surfaktan, dan pengaruhnya terhadap efesiensi penyimpanan kation dan kapasitas memegang air. Agritech, 29(1), pp. 36-41.

Utami, S. N. H., Ma'as, A., Radjagukguk, B., and Purwanto, B. H. (2009b). Sifat fisik, kimia dan FTIR spektrofotometri gambut hidrofobik 
Kalimantan Tengah. Jurnal Tanah Tropika, 14(2), pp. 159-166.

Wang, M., Talbot, J., and Moore, T. R. (2018). Drainage and fertilization effects on nutrient availability in an ombrotrophic peatland. Science of the Total Environment, 621, pp. 1255-1263.

Winarna, Murtilaksono, K., Sabihan, S., Sutandi, A., and Sutarta, E. S. (2016). Hydrophobicity of tropical peat soil from an oil palm plantation in North Sumatra. Journal of Agronomy, 15(3), pp. 114-121.

Winarna, (2015). Pengaruh kedalaman muka air tanah dan dosis terak baja terhadap hidrofobisitas tanah gambut, emisi karbon, dan produksi kelapa sawit. Dissertation. Institut Pertanian Bogor.
Wu, Y., Zhang, N., Slater, G., Waddington, J. M., and Lannoy, C. D. (2020). Hydrophobicity of peat soils: Characterization of organic compound changes associated with heat-induced water repellency. Science of the Total Environment, 714, pp. 1-15.

Zabowski, D and Ugolini, F.C. (1990). Lysimeter and soil solutions: seasonal differences between methods. Soil Science Society of America Journal, 54(4), pp. 1130-1135. 